\title{
ŽEMDIRBIŲ GAMINTOJŲ ORGANIZACIJŲ FORMAVIMAS
}

\author{
JAN ŽUKOVSKIS ${ }^{1}$, JuLIUS RAMANAUSKAS ${ }^{2}$
}

Aleksandro Stulginskio universitetas ${ }^{1}$, Klaipėdos universitetas ${ }^{2}$ (Lietuva)

\begin{abstract}
ANOTACIJA
Lietuvos žemės ūkio sektoriuje vyrauja smulkūs ūkiai, kuriems veikti rinkos sąlygomis sudètinga. Tad noredami įgyti konkurencinị pranašumą, valdyti žemės ūkio produkcijos rinkas, gerinti produkcijos kokybę, spręsti socialinius ir aplinkosaugos klausimus, turi jungtis ị didesnius darinius - steigti kooperatyvus ir gamintojų organizacijas. Tyrimu siekta atskleisti gamintojų organizacijų (GO) raidą ES šalyse ir pasiūlyti būdų, kaip sparčiau vystytis Lietuvoje? Darbe atlikta ekonominès literatūros ir teisinès dokumentacijos žemės ūkio produkcijos rinkų reguliavimo ir žemdirbių kooperatyvų klausimais analizè. Taikytas iš dalies standartizuotas interviu su Lietuvos ir Airijos, Italijos, Latvijos, Lenkijos, Olandijos, Prancūzijos, Švedijos, Vokietijos kooperatyvų bei GO vadovais ir specialistais. Siekiant aktyvinti kooperatyvus ir GO, būtina parengti ir priimti ilgalaikę strategiją, kurioje numatyti gamintojų organizacijų plètros kryptis ir pagrindines priemones: produkcijos realizavimas, ūkininkų ir kooperatyvų vadovų mokymai (konsultavimas), paramos gavimo supaprastinimas ir kt.

PAGRINDINIAI ŽODŽIAI: gamintojų organizacija, kooperatinè bendrove (kooperatyvas), veiksmu programa, finansiné parama.
\end{abstract}

JEL KLASIFIKACIJA: Q01, Q13, Q17.

Ivadas

Lietuvos žemės ūkio sektoriuje vyrauja smulkūs ūkiai, kuriems sudètinga veikti rinkos sąlygomis. Tad norint igyti konkurencini pranašumą, valdyti žemès ūkio produkcijos rinkas, gerinti produkcijos kokybę, spręsti socialinius ir aplinkosaugos klausimus, jiems būtina jungtis ị didesnius darinius steigiant gamintojų organizacijas (toliau - GO). Deja, tokių organizacijų kaip kooperatyvai plètra Lietuvoje dẻl ịvairių priežasčiu (Kriščiukaitienè, 2015; Kuliešis, 2010; Pareigienè, 2008; Skulskis, 2014; Vidickienè, 2009) stringa, o įsikūrę kooperatyvai yra maži ir negali konkuruoti rinkoje su akcinèmis bendrovėmis.

Lietuvoje GO įteisintos dar 2002 m. LR Žemès ūkio ir kaimo plètros įstatyme, tačiau iki šiol sukurta tik viena vaisių daržovių ir 4 formalios žuvininkystės GO. Spartesnę GO plètrą stabdo neišspręstos problemos: psichologinès, ekonominès, organizacinès, teisinès ir kt. Nėra aiškių motyvacinių priemonių, kaip skatinti ūkininkus bendradarbiauti, bendrai vykdyti tam tikras prekybos ar kitas operacijas. Be to, GO kūrimąsi stabdo kooperatyvų dydis, neužtikrinantis reikiamo per juos vykdomos prekybos apyvartos masto, kuris motyvuotų siekti GO numatytos rinkodaros plètros paramos.

Tyrimo problema: GO raida paskirose ES šalyse, būtinos priemonès, galinčios padèti joms sparčiau vystytis Lietuvoje?

1 Jan Žukovskis - docentas, daktaras (ekonomika), Aleksandro Stulginskio universiteto Ekonomikos ir vadybos fakulteto Verslo ir kaimo plètros vadybos institutas. Moksliniai interesai: žemės ūkio ir kaimo plètros administravimo sistemos reglamentavimas, socialinių sistemų (organizacijų) vadyba

El.paštas: jan.zukovskis@asu.lt

Tel. +370 69816243

2 Julius Ramanauskas - profesorius, habilituotas daktaras. Klaipėdos universiteto Socialinių mokslų fakulteto Vadybos katedra. Moksliniai interesai: kaimo plètra, inovacijų vadyba

El. paštas: julius.ramanauskas@asu.lt

Tel. +370 69817677 
Tyrimo tikslas - parengti žemdirbių gamintojų organizacijų kūrimosi skatinimo priemones.

Tyrimo metodika. Darbe atlikta ekonominès literatūros ir teisinès dokumentacijos žemès ūkio produkcijos rinkų reguliavimo ir žemdirbių kooperatyvų klausimais analizè. Taikytas iš dalies standartizuoto interviu metodas su Lietuvos, Airijos, Italijos, Latvijos, Lenkijos, Olandijos, Prancūzijos, Švedijos, Vokietijos kooperatyvų ir GO vadovais bei specialistais. Pokalbiai griežtai neformalizuoti, todèl klausèjo ir respondento pokalbio atmosfera buvo laisvesnè. Kai kurie būtini klausimai iš dalies standartizuoti, numatyti iš anksto. Taip surinkta informacija apie kooperatyvų ir GO kūrimosi bei veiklos patirtį. Išanalizavus produkcijos pardavimo tvarką, teikiamą paramą, GO kūrimosi problemas, dokumentų tvarkymą, planavimo, organizavimo, valdymo, kontrolès ir apskaitos tvarką, nustatyti paskirų ES šalių GO steigimosi ir veiklos ypatumai.

Tyrimo metodai: internetinių šaltinių, literatūros ir teisès dokumentų analizè, analogijų taikymas, duomenų statistinès analizès metodas. Duomenys rinkti taikant iš dalies standartizuotą (struktūruotą) interviu. Šis metodas pagrịstas tuo, kad dalis klausimų parengta iš anksto ir griežtai apibrěžta, vèliau interviu papildytas kitais klausimais ir atsakymais. Duomenys analizuoti taikant indukcinị samprotavimų metodą.

Darbo rezultatus gali panaudoti GO, rengdamos veiklos programas, Nacionaliné mokèjimo agentūra prie Lietuvos Respublikos žemès ūkio ministerijos, pripažindama pavienius juridinius asmenis kaip GO bei vykdydama jų veiklos kontrolę.

\section{Kooperatyvų ir GO raida užsienio šalyse}

Žemės ūkio ir kaimo plètros dokumentuose (Dèl žemės ūkio..., 2000; Dèl LR Vyriausybès programos, 2012) pabrèžiama, kad kooperacija žemės ūkyje yra viena iš prioritetinių sričių, o vienas svarių kooperatyvu plètros skatinimo veiksniu - ES taikoma ypatinga priemoné - gamintojų grupių / organizacijų statuso suteikimas. Beje, kai kuriose ES šalyse kaip GO pripažįstami ne tik kooperatyvai, bet ir kiti juridiniai asmenys: ribotos atsakomybès bendrovès, asociacijos. GO ne tik organizuoja kooperuotą prekybos ir paslaugų teikimo veiklą, bet ir kuria agrarinę politiką (Bingen, 1999; Ramanauskas, 2013).

Žemdirbių organizuotų veiksmų poreikis atsiranda žemès ūkio produktų gamybai tampant prekine (Wiatrak, 2015). Bet steigiant kooperatyvus ir GO reikia atsižvelgti ị kiekvienos šalies ypatumus. Suomijos mokslininkas P. Ollila (2009) įrodè, kad kooperatyvai - išskirtinès hierarchinio koordinavimo pobūdžio institucijos, veikiančios rinkoje. Bet norint pripažinti kooperatyvą kaip GO, būtina atsižvelgti ị besikeičiančias rinkos sąlygas. Švedijos mokslininkė L. Westerlund-Lind (2011) savo disertacijoje aptare bendras Švedijos kooperatyvų problemas, kada kooperacija nesukuria pridètinès vertės, o kooperatyvo išlaikymas kainuoja brangiau nei gaunama nauda. Be to, GO keliami nemaži reikalavimai, nariams ne visada aiškios stojimo ị organizaciją sąlygos. Taip Prancūzijoje ši aplinkybė paskatino kai kuriuos narius išstoti iš GO (Chazoule, 2005).

Tam tikrose šalyse GO veiklos vystymasis priklauso nuo sektoriaus išsivystymo lygio. Pavyzdžiui, Nyderlanduose ar Belgijoje vaisių ir daržovių auginimo mastai yra labai dideli, todèl GO veiksmų programose dominuoja energijos taupymo, gruntinių vandenų naudojimo šildymui, produktų rinkodaros priemonès (Klaasen, 2007).

Kai kuriose postkomunistinėse šalyse (pvz., Lenkijoje) GO sąvoka vartojama apibūdinti ir žemdirbių bendradarbiavimo, tikrojo kooperatinio judèjimo reiškini (Oleszko-Kurzyna, 2007; Ejsmont, 2005). Todėl Lenkijoje GO skiriamas didžiulis dèmesys, ypač daug autorių nagrinèja žemdirbių bendros veiklos ekonominę, organizacinę ir socialinę naudą (Chlebicka, 2008; Krzyżanowska, 2003; Lemanowicz, 2004; Prus, 2009).

Atsižvelgiant ị užsibrèžtus tikslus ir organizacinę teisinę formą, žemdirbių kooperatyvas ir GO gali vykdyti šias funkcijas (Sposoby, 2008):

- gamintojų veiklos organizavimas;

- produkcijos pardavimas ir pirkimas;

- klientų paieška ir nuolatinių ryšių su jais palaikymas;

- informacijos apie rinkas rinkimas ir apdorojimas, užtikrinant reikiamą skaidrumą; 
- $\quad$ situacijos rinkoje analizè, planavimas ir rinkoje vykstančių pokyčių trumpuoju bei ilguoju laikotarpiu numatymas;

- gamybos potencialo didinimas, pageidaujamų žemès ūkio produktų rūšių ir veislių atranka;

- specializacijos lygio ir specializuotos produkcijos apimčių didinimas;

- pagrįstų gamybos profilio pokyčių vykdymas;

- gamybos intensyvinimas;

- produktų ir paslaugų rèmimas;

- produktų pritaikymas vartotojų poreikiams: pakavimas, paruošimas, standartizavimas, kokybinių charakteristikų apibrēžimas;

- derybų vedimas;

- fizinis prekių paskirstymas: saugojimas, sandèliavimas, transportavimas, laikantis logistikos principų, pageidaujamo prekių kiekio paruošimas;

- rizikos prisièmimas ir jos mažinimas, taikant draudimą, garantijas ir kitas priemones;

- kompleksinių atsiskaitymų vykdymas;

- mokymai.

2010 m. ES valstybėse narèse buvo apie 1600 pripažintų GO, nors pavienių valstybių lygiai gerokai skiriasi (1 pav.).

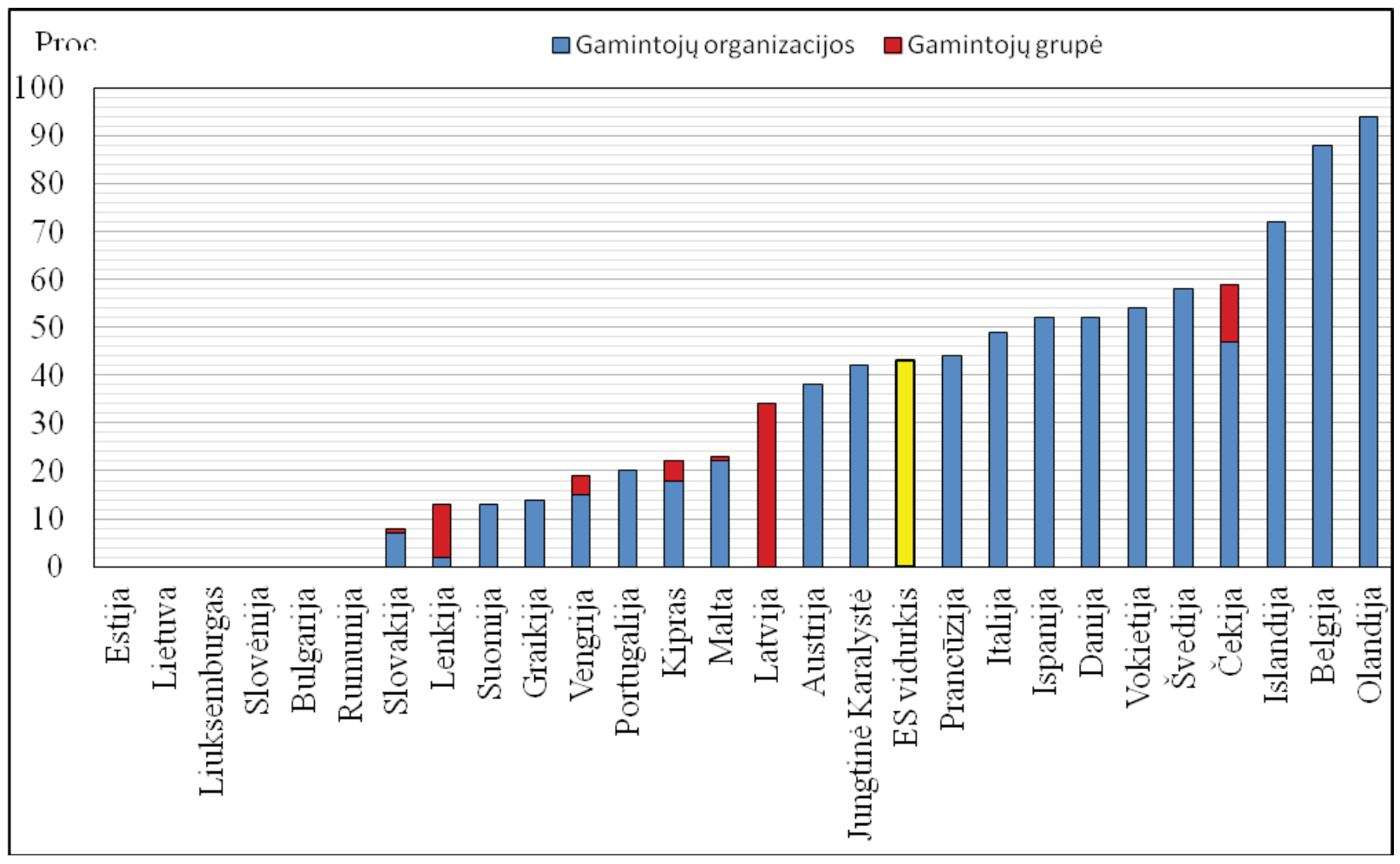

1 pav. Vaisių ir daržovių sektoriaus jungimosi ị organizacijas lygis pagal valstybes nares $2010 \mathrm{~m}$.

(Report from..., 2014)

Vertinant GO vaidmeni konkrečiam sektoriui, ES vartojama organizuotumo arba kooperacijos lygio sąvoka (angl. organisation rate) apibūdinti procentini santykị tarp GO narių realizuotos ir šalies mastu išaugintos produkcijos. $2010 \mathrm{~m}$. vaisių ir daržovių sektoriuje organizuotumo lygis ES buvo apie 43,0 proc. (43,9 proc., ịskaičius gamintojų grupes).

Organizuotumo lygis - tai rodiklis, kuris skaičiuojamas kaip gamintojų organizacijų ir bendrų to sektoriaus produkcijos pardavimų santykis. Šis rodiklis pavienèse valstybėse nevienodas. Pvz., Olandijoje ir Airijoje - apie 90 proc., Italijoje - 47 proc., Prancūzijoje - apie 47 proc. Kai kuriose valstybėse yra labai 
nedaug GO, joms tenkanti rinkos produkcijos dalis yra labai nedidelè. Be to, ES valstybèse skiriasi augintojų jungimosi ị GO pagal regionus rodiklių reikšmès. GO plètrą kai kuriose valstybėse apsunkina ịvairūs veiksniai (Bijmans, 2013): pasitikèjimo kaimynais nebuvimas, įtarumas, pagunda nemokèti mokesčių, nes nepriklausomi ūkininkai gauna didesni pelną iš neskelbiamų pardavimų (,juodoji rinka“). Be to, daugelis ūkininkų parduoda produktus nusistovejjusiose rinkose arba tiesiogiai ir jiems nesvarbi narystės GO teikiama nauda. Svarbus GO plètros trikdis - sudètinga ir brangi GO ịsisteigimo pripažinimo ir galimybès gauti finansinę pagalbą procedūra, todèl GO privalumai yra mažesni nei administracinès išlaidos. Reikšminga ir tai, kad rizikuojama netekti ES paramos, nes GO būtina laikytis pripažinimo kriterijų: narių skaičius, demokratinè kontrolè, visos produkcijos centralizuotas tiekimas rinkai. Būtent todèl 2004-2010 m. daugiausia pripažinimų GO buvo panaikinta Ispanijoje (148), Prancūzijoje (94) ir Italijoje (43), nemažai jų panaikinta Slovėnijoje, Airijoje, Suomijoje ir Bulgarijoje.

Airijos kooperatyvai veikia savitai, nes šalyje nèra specialaus kooperacijos įstatymo, kur būtų nurodyta viena pamatinių taisyklių: „Vienas žmogus - vienas balsas.“ Kooperatyvai neturi jokių mokestinių lengvatų, kiekvienas kooperatyvas parengia ịstatus, kur nusistato savas balsavimo taisykles. Airijos kooperatyvuose gali būti ir neaktyvių narių, kurie tik finansiškai palaiko organizaciją.

Pagal organizuotumo lygio rodiklị Airija (90 proc.) yra viena pirmaujančių ES, nors teturi tik dvi GO. GO pradejjo steigtis 1999 m. ir iki $2002 \mathrm{~m}$. jų buvo jau 17. Iš jų 13-a - grybų augintojai. Dèl nedidelio narių skaičiaus ir mažos apyvartos mažosios GO neišsilaikè ir prasidèjo konsolidacijos laikotarpis. Iki 2008 m. beliko dvi grybų augintojų GO, šiuo metu veikia tik viena didelè grybų augintojų GO - Commercial Mushroom Producers (CMP). Ji yra viena pirmaujančiu Europoje, sujungusi daugiau nei 90 proc. Airijos grybu augintojų, turi ir narių iš užsienio šalių. CMP registruota kaip uždaroji akcinė bendrovè.

2007 m. devyni iš daugiau kaip 200 atviro grunto daržovių augintojų priklausẻ GO, bet dèl mažų apimčių (produkcijos realizuodavo apytikriai už $3,7 \mathrm{mln}$. eurų) šis GO neišsilaikè ir šiuo metu daržininkystès srityje GO Airijoje nèra. Penki vaisių ir uogų augintojai buvo sukūrę GO, bet šiuo metu ji neegzistuoja. Veikia uždaro grunto augintojų GO (20 narių), kurių apyvarta viršija $40 \mathrm{mln}$. eurų.

Didžiausia plètros problema - platūs prekybos tinklai ir didmenininkai, jau sukūrę savo perdirbimo, rūšiavimo, pakavimo infrastruktūrą, palaikantys glaudžius ryšius su augintojais. Tik susikūrusioms GO buvo beveik neįmanoma patekti ị rinką.

Airijos GO specifika - augintojų iš užsienio šalių dalyvavimas. Ypač tai buvo pastebima vaisių ir daržovių sektoriuose, kur Airijos ūkininkai tesudare 6-14 proc., esant stipriai grybų augintojų organizacijai, šis skaičius siekė 95 proc. Užsienio ūkininkų dalyvavimas praplečia produkcijos apimtis importine produkcija ir atveria eksporto rinkas.

Šiuo metu pripažintos GO metinè apyvarta turètų siekti ne mažiau kaip 1,5 mln. eurų.

Airijos GO organizacijų veiklos programose, be bendru gamtos apsaugos, krizès valdymo, produkcijos kokybès ir kt. reikalavimų, yra ir specifinių krypčių:

- didinti produkcijos vertę, kuriant naujus produktus;

- didinti vaisių ir daržovių vartojimą, kartu ir GO apyvartą;

- $\quad$ sukurti GO prekès ženklą, kurị pripažintų vartotojas, norintis, kad rinkoje būtų kuo daugiau šio produkto.

Kooperatyvai Italijoje gana populiari įmonès forma. Čia veikia 8100 žemės ūkio kooperatyvų, 97,3 proc. iš jų yra iš esmès savitarpio pagalbos kooperatyvai (angl. mainly mutual). Centrinè kooperatyvų asociacija „Centrali cooperative di rappresentanza“ subūrusi 5835 aktyvius kooperatyvus, kurie turi daugiau nei 863 tūkst. narių. Juose dirba apie 94 tūkst. darbuotojų. Bendra apyvarta - apie $34 \mathrm{mlrd}$. eurų. Italijoje dalis kooperatyvų jungiasi ị asociacijas ir yra pripažinti GO (Evaluation..., 2012). Per 2008-2012 m. laikotarpị bendras GO skaičius šiek tiek mažejo (nuo 296 iki 278), nes jos būrèsi i asociacijas, kurios savo ruožtu pripažintos GO. Italijoje santykinai aukštas nacionalinis telkimosi į organizacijas lygis (apie 47 \%) yra aukšto organizavimosi lygio kai kuriuose šiaurès regionuose ir žemo organizavimosi lygio keliuose kituose regionuose rezultatas. 
Latvijoje veikia tik trys vaisių ir daržovių augintojų kooperatyvai, pripažinti GO, bet jie kontroliuoja daugiau nei trečdali vaisių ir daržovių apyvartos (Komisijos..., 2014).

Paskutiniajam praējusio amžiaus dešimtmečiui tiek Lenkijos, tiek Lietuvos žemdirbiams būdingas nepalankus požiūris ị kooperaciją. Valstybės kontroliuojamų kooperatyvų vietą užėmė tarpininkai. Situacija pradèjo gerèti $2000 \mathrm{~m}$. pabaigoje prièmus įstatymą dèl žemdirbių gamintojų grupių. Nors akivaizdi nuolatinè GO skaičiaus augimo tendencija, tačiau daugelis autorių (Boguta, 2014; Chlebicka, 2011; Wiatrak, 2015) nurodo, kad žemdirbių telkimosi lygis vis dar yra žemas. $2014 \mathrm{~m}$. gamintojų grupès apėmè tik 0,08 proc. visų ūkių ir 0,19 proc. didesnių kaip 5 ha ūkių (Wiatrak, 2015). Kaip teigia W. Boguta (2014), tik 15 proc. iš maždaug 250 tūkst. žemdirbių, gaminančiu produkciją rinkai didesniu mastu - taigi potencialių GO kūrèjų, yra jų nariai. Vis dèlto, nepaisant nemažos pažangos steigiant GO, Lenkijoje gamintojų organizuotumo lygis dar gana žemas ir tai yra vienas didžiausių žemès ūkio trūkumų (Chlebicka, 2008). 2014 m. Lenkijoje veikè daugiau kaip 300 GO. Ypač sparčiai jos kūrèsi vykdant 2007-2013 m. Kaimo plètros programą. GO skaičiaus augimas Lenkijoje buvo sprogstamojo pobūdžio ir sukẻlė finansinių problemų ES biudžete: vaisių ir daržovių GO pritrūko pinigų. Planuotos metinès ES paramos lèšos visoms vaisių ir daržovių GO sudare 30$40 \mathrm{mln}$. eurų, faktiškai prašoma parama $2011 \mathrm{~m}$. pasiekè $195 \mathrm{mln}$. eurų, iš to Lenkijai - $180 \mathrm{mln}$. eurų. Dèl to nuo $2012 \mathrm{~m}$. įvesti GO finansavimo apribojimai ir dabar vienai GO vidutiniškai tenka apie $1,5 \mathrm{mln}$. euru paramos. Didžioji paramos dalis (92,5 proc.) tenka GO pripažinimo planuose numatytoms investicijoms. Pasinaudojusios parama, jos pirko modernias ir našias vaisių bei daržovių surinkimo mašinas, specializuotus automobilius produktams gabenti ị didmenines bazes ir parduotuves, statè nuosavas šaldyklas ir sandèlius, irrenginèjo rūšiavimo ir pakavimo linijas.

Nors šiandien vaisių ir daržovių augintojų kooperacijos lygis Lenkijoje yra vienas aukščiausių, apklausa atskleidè, kad nemažai GO ịsisteigè ne dèl bendros kooperatinès naudos, bet tik tam, kad gautų finansinę paramą. Nesant paramos, GO gali iširti. Šioje šalyje pripažistama, kad GO vaidina svarbų vaidmenị stabilizuojant žemès ūkio ir maisto produktų rinkas.

Vokietijos žemès ūkio sektoriuje ir maisto pramoneje veikia beveik 2400 aktyvių kooperatinių bendrovių, turinčių 1441 tūkst. narių, jose dirba 97,3 darbuotojų, bendra apyvarta siekia daugiau kaip 67,5 mln. euru (Development of..., 2015). Kooperatyvai vidutiniškai užima maždaug 50 proc. rinkos dalies. Be to, Rytu Vokietijoje maždaug trečdalis žemès ūkio naudmenų ploto dirbama kelių susikooperavusių šeimų. Bendra Raifaiseno kooperatyvų apyvarta 2013 metais siekè 68 mlrd. eurų.

Kuriant GO ypač naudinga Olandijos patirtis, nes ten GO nariais yra beveik visi ūkininkai (apie 90 proc.). Smulkesnès Olandijos GO, teisingai reaguodamos ị besikeičiančią rinkos dinamiką, susibūrè i stambesnius darinius. Šiuo metu veikia 21 didelè GO, nes nuo 1996 iki 2010 metų narių skaičius sumažèjo nuo 11000 iki 1600, bet vidutinè apyvarta iš vieno nario padidèjo nuo 120 iki 550 tūkst. eurų per metus. Stambejimo procesas vyksta ir šiandien. (žr. 1 lentelę)

Prancūzijos kooperatyvai yra susibūrę ì skètinę organizaciją „Coop-de-France“, kuri sujungusi 2400 žemès ūkio srities kooperatyvų ir 11,5 tūkst. žemės ūkio technikos kooperatyvų. Daugiausia yra vyno gamybos (690), pienininkystès ir vaisių bei daržovių auginimo (250) kooperatyvų. Iš viso kooperatyvų veikloje dalyvauja daugiau kaip 858 tūkst. ūkininkų, kurių bendra apyvarta siekia daugiau kaip 84 mln. eurų.

Švedijoje kooperatyvai pastaruoju metu konsoliduojasi - jų skaičius mažèja, bet patys kooperatyvai didejja. Žemès ūkio kooperatyvus reprezentuoja centrinè organizacija LRF. Daugelis kooperatyvų investuoja ir plečiasi užsienio šalyse, ypač glaudžius ryšius palaiko su Danija ir Norvegija. Susikūrę tarptautiniai kooperatyvai palengvina prekių judèjimą, produktų realizavimą, supaprastina žemdirbių aptarnavimą. Švedijos žemės ūkio kooperatyvų reikšmė šalies ekonomikoje pastaruoju metu mažèja, nes šalyje vis daugiau veikia Danijos ir Suomijos kooperatyvų. Pavyzdžiui, mėsos ir pieno sektorius visiškai valdo Suomijos ir Danijos kooperatyvai, grūdų sektorius vis dar priklauso Švedijos kooperatyvams, bet ir čia jaučiama didèjanti Danijos konkurencija.

Lyginant su kitomis ES šalimis, Švedija GO skaičiumi ir jų dydžiu šiek tiek atsilieka nuo vidurkio, tačiau per GO realizuotos produkcijos dalimi ji lenkia ES šalių vidurkį. Nors GO Švedijoje veikè dar prieš stojant ị 
ES, po 1996 m. jos praèjo ES pripažinimo procedūras. 1997 m. susikūrè 11 GO. Vèliau vienos susijungè, kitos steigèsi, šiuo metu Švedijoje yra 9 vaisių ir daržovių GO. Keturios didžiosios GO realizuoja produkcijos už $130 \mathrm{mln}$. eurų.

Švedijos vaisių ir daržovių dalis, realizuota per GO, gana pastovi ir sudaro $40-45$ proc. Tiesa, paskirų rūšių dalis skirtinga: dauguma žiedinių kopūstų ir pomidorų parduodama per GO, tačiau daugiausia parduodamų kultūrų (kaip morkos ar braškės) per GO tesudaro kelis procentus. Be vaisių ir daržovių GO, Švedijoje veikia žvejų ir miško augintojų GO.

1 lentelè. Olandijos gamintojų organizacijų (kooperatyvų) veiklos pobūdis (remiantis interviu su gamintojų organizacijos „Reo Veiling“vadovais)

\begin{tabular}{|l|c|c|}
\hline \multicolumn{1}{|c|}{ Veiklos pobūdis } & \multicolumn{2}{c|}{ Veiklos } \\
\cline { 2 - 3 } & Tradicinès & Naujos \\
\hline Pardavimai & + & + \\
\hline Pardavimų administravimas (atsiskaitymo kontrolė) & + & + \\
\hline Produkcijos kokybės kontrolė & + & + \\
\hline Logistika & + & + \\
\hline Produkcijos kokybės standartų diegimas ir užtikrinimas + prekių kilmės žymėjimas & + & + \\
\hline Trumpalaikis ir ilgalaikis sandėliavimas & & + \\
\hline Rinkodara + skatinimas & & + \\
\hline Inovacijos + tyrimai & & + \\
\hline Didmeninè prekyba +eksportas & & + \\
\hline Aplinkosaugos priemonès & & + \\
\hline Perdirbimas (tam tikros produkcijos) & & + \\
\hline Pagalba augintojui & & + \\
\hline
\end{tabular}

\section{Kooperatyvų ir GO raida Lietuvoje}

Šiuo metu žemdirbių dalyvavimas savo produkcijos perdirbimo procese dèl ịvairiu priežasčiu ribotas, todèl jie nedaro didesnès ịtakos formuojant produktų kainas. Kai kurie autoriai teigia, kad kooperatyvas gali apginti savo narius, sustiprinti jų konkurencinę galią santykiuose su produkcijos pirkèjais ir išteklių tiekejjais (Vaznonis, 2008).

Dabartinei bendrai žemès ūkio politikai būdingas finansinès paramos atsiejimas nuo gamybos apimties, kartais ir tos paramos priklausomybė nuo gamybos mažinimo bei žemės ūkio gamybos veiksnių - žemès ir darbo - įtakos mažejimo. Taikomos priemonès turi paskatinti žemdirbius imtis veiksmų didinti ne gamybos apimtis, bet efektyvumą. Tikètina, kad finansinè parama žemès ūkiui mažès, taigi reikia skatinti tuos veiksmus, kurie stiprintų žemès ūkio produkcijos gamintojų rinkos poziciją. Žemdirbiai, naudodami paramą, turi pasirūpinti tuo, kad jų konkurencinè pozicija santykiuose su produkcijos pirkejjais stiprètų. Integraciniai veiksmai - teisingas to siekimo būdas. Žemdirbių GO turi tapti pagrindine organizuotos žemès ūkio rinkos grandine.

Taigi siekiant aktyvinti kooperatyvų ir GO veiklą, būtina ilgalaike strategija, kur turi būti numatytos pagrindinès veiklos priemonès: produkcijos realizavimas, ūkininkų ir kooperatyvų vadovų mokymai (konsultavimas), paramos gavimo supaprastinimas ir kt.

Lietuvoje GO ịteisintos dar 2002 m. LR Žemès ūkio ir kaimo plètros ịstatyme. Teisiniu požiūriu (formaliai) ES GO - tai , „ivykdęs nustatytus pripažinimo reikalavimus ir ES reglamentų ir nacionalinès teisès aktų nustatyta tvarka pripažintas juridinis asmuo, jungiantis žemès ūkio produkcijos gamintojus, turintis teisę gauti finansinę paramą“" (Pieno..., 2015). Pripažintos GO ịrašomos į nacionalinị GO registrą. Neformaliai gamintojų organizacija galima vadinti bet kurị žemdirbių susijungimą siekiant bendrų tikslų: auginti (gaminti) produkciją, ją perdirbti, realizuoti ir pan. Tai gali būti kooperatyvas, asociacija, žemès ūkio bendrovè, bendrija, UAB ir kt. 
Paminètina, kad susijungimo ị formalias GO procesas yra gana sudètingas, pasitaiko nemažai kliūčių. Svarbiausias dalykas - psichologinių barjerų ịveikimas, pozityvių bendros veiklos pavyzdžių formavimas, galimybės naudotis kompetentingomis konsultacijomis sudarymas.

Kooperatyvų ir GO kūrimosi proceso Lietuvoje ir kitose šalyse analizė atskleide daug aktualių ir neišspręstų psichologijos, ekonomikos, organizavimo, teisès ir konsultavimo problemų (Pareigienė, 2008; Pateikti pasiūlymus..., 2001 ir kt.). Daugelis autorių pabrèžia, kad didelę neigiamą įtaką darè negatyvi istorinė visuotinio suvisuomeninimo patirtis (neigiama kolūkių patirtis).

Nors bendra veikla GO žemdirbiams teikia didelę ekonominę naudą, jos plètrą riboja įvairios socialinès kliūtys: išsilavinimo ir žinių trūkumas, tradicinis bet kokių permainų vengimas, nepasitikèjimas potencialiais partneriais, nenoras vykdyti organizacines inovacijas, lyderių trūkumas ar nenoras vykdyti (dažnai neatlygintinai) lyderio funkcijas ar tiesiog negebejjimas tų funkcijų vykdyti. Vis dar žemas žemdirbių susitelkimo laipsnis rodo, kad sudètinga surinkti keliolika vieno produkto gamintojų, norinčių bendrai vykdyti ūkinę veiklą, nes Lietuvoje labai skiriasi ūkių dydžiai.

Šiuo metu Lietuvoje GO gali būti pripažintos (ir tam yra parengta teisinė bazė) žuvininkystès ir akvakultūros, vaisių ir daržovių bei pieno sektoriuose. Lietuvos kaimo plètros 2014-2020 m. programoje numatyti kitų žemès ūkio sektorių gamintojų organizacijų pripažinimo ir paramos joms teikimo pagrindiniai principai, jų taikymo taisyklès rengiamos.

\section{1. Žuvininkystès ir akvakultūros GO}

Žuvininkystès ir akvakultūros produktų bendrojo rinkos organizavimo (BRO) numatomas kainų reguliavimo ir intervencijos sistemos tikslas - reguliuoti žuvininkystės produktų rinką ${ }^{3}$. Šio sektoriaus rinkų organizavimo ES Tarybos reglamentas (EB) Nr. 104/2000 priimtas dar 1999 metais. Šiuo reglamento pagrindu LR žemès ūkio ministro 2002 m. balandžio 15 d. įsakymu Nr. 134 „Dèl bendrosios žuvininkystès produktu rinkos organizavimo tvarkos patvirtinimo" priimtos Žuvininkystès produktų GO pripažinimo ir pripažinimo panaikinimo taisyklès.

Yra tik 4 pripažintos tarpšakinès organizacijos, veikiančios valstybės lygmeniu: „Comité Interprofessionnel des Produits de l'Aquaculture“ - C.I.P.A. (Prancūzija), „Interatún“ (Ispanija), „Aquapiscis“ (Ispanija) ir O.I. „Filliera Ittica“ (Italija). Lietuvoje šiuo metu pripažintos ir sėkmingai veikia 3 žuvininkystès ir akvakultūros produktų GO, kurias sukūre: Lietuvos žuvininkystės produktų gamintojų asociacija, Žuvininkystės įmonių asociacija „Lampetra“ ir Nacionalinė akvakultūros ir žuvų produktų gamintojų asociacija.

\subsection{Vaisių ir daržovių GO}

Lietuvoje teisiniu požiūriu iki 2012 m. galëjo būti įteisintos tik vaisių ir daržovių GO. Siekiant padèti augintojams geriau prisitaikyti prie bendrojo rinkos organizavimo, Lietuvoje vaisių ir daržovių GO pripažinimo ir finansinio rẻmimo taisyklès parengtos ir priimtos dar prieš stojant ị ES, tačiau dèl daugelio socialinių-psichologinių ir organizacinių-ekonominių priežasčių iki šiol pripažinta tik viena GO - žemès ūkio kooperatyvas „Agrolit“.

\subsection{Pieno GO}

Lietuvos ir pasaulinė pieno produktų rinka nèra stabili, nes pieno produktų paklausa išlieka didelè, tačiau ir pieno gamyba dideja visose šalyse. Vis dèlto pieno perdirbejjai nuolat mažina kainas, todèl žemdirbiams būtina imtis priemonių stiprinti pieno gamintojų pozicijas. Viena rimčiausių priemonių - didesnè pieno gamintojų koncentracija pripažistant GO ir jų asociacijas.

$2012 \mathrm{~m}$. siekdamas užtikrinti pieno sektoriaus plètrą ir stiprinti pieno gamintojų pozicijas sudarant pieno pirkimo ir pardavimo sutartis, LR žemès ūkio ministras 2012 m. rugpjūčio 13 d. ịsakymu Nr. 3D-658 patvirtino Pieno GO ir jų asociacijų administravimo taisykles (Pieno..., 2012).

\footnotetext{
3 Prieiga internete: www.europarl.europa.eu
} 


\section{3. Žemdirbių kooperacijos ir GO veiklos aktyvinimas}

Remiantis ES reglamentais, žemdirbių GO gali būti pripažinti ịvairūs juridiniai asmenys. Siekiant nustatyti, kuri juridine forma labiausiai atitinka GO pripažinimo reikalavimus, atlikta įvairių juridinio statuso įmonių įstatymų analizè (Vaznonis, 2007; 2014). Iš atlikto tyrimo paaiškèjo, kad visus pripažinimo GO juridinių asmenų reikalavimus visiškai atitinka tik kooperatyvas, todèl pripažinimo GO turètų siekti jau veikiantys ar besisteigiantys žemdirbiu kooperatyvai. Deja, kooperatyvai Lietuvoje maži, o mažo kooperatyvo, gavusio GO pripažinimą, nariams bus mažai naudos, nes galimos paramos dydis priklauso nuo per organizaciją vykdomos apyvartos. Be to, smulkūs augintojai neturi pakankamai lèšų steigti ir išlaikyti kooperatyvą (sudètinga visus metus išlaikyti administraciją, patalpas), o dẻl mažos kooperatyvo apyvartos jiems neįmanoma užimti tinkamos vietos ir išsilaikyti rinkoje. Taigi kooperatyvų dydis - viena priežasčių, kodèl šiuo metu šalyje pripažinta tik viena gamintojų grupè ir visai nèra GO. Kita vertus, atstumai tarp augintojų dideli, todėl jiems sunku susiburti ị kooperatyvą.

Taigi norint Lietuvoje plètoti kooperatyvus, dalykinis ir organizacinis žemdirbių formalių GO kūrimasis tiesiog būtinas. Tai byloja ịvairių ES šalių patirtis. Tačiau viena iš dažnai nurodomų priežasčių, kodèl Lietuvoje nesikuria GO, - per maža parama. Tyrimo metu, bendraujant su kai kurių kooperatyvų vadovais, paaiškėjo, kad daugelio Lietuvos kooperatyvų apyvarta yra nedidelè, todèl dèl 4,1 proc. nuo apyvartos dydžio paramos neverta rengti dokumentų, siekiant GO statuso, ir įsipareigoti vykdyti veiksmų programą, tačiau dažnai neatsižvelgiama ị galimybes, kurias teikia vaisių ir daržovių GO statusas.

Dabartinis teisinis reguliavimas išties patrauklus dideliems ūkiams, kurie ir taip yra stambūs ūkio subjektai. Smulkiems ir vidutiniams ūkiams paskatų nepakanka, todèl tikslinga nustatyti diferencijuotą rèmimo sistemą: teikti didesnę finansinę paramą GO, apimančioms smulkius ir vidutinius ūkininkus, prioritetą teikiant didesniam ị kooperatyvą susijungusių narių skaičiui.

Galima išeitis - stambesnių kooperatyvų, kurių apyvarta didelè, kūrimosi skatinimas, jie vèliau galètų tapti veiksmingai veikiančiomis GO. Tai įmanoma kuriant kooperatyvus integruojančią sistemą, sujungiančią smulkiuosius ir stambiuosius augintojus. Pagal siūlomą modelị numatomas paskirų produktų grupių vietinių kooperatyvų susijungimas ị didesnius regioninius kooperatyvus ir GO, kurie galėtų siekti pripažinimo kaip GO asociacija. Toks jungimasis vyktų teritoriniu pagrindu. Galètų formuotis vietiniai (arba pirmojo lygio), regioniniai (arba antrojo lygio), visos šalies (arba trečiojo lygio) ir tarptautiniai kooperatiniai dariniai. Tokia ịvairaus lygio kooperatyvus integruojanti sistema pavaizduota 2 paveiksle.

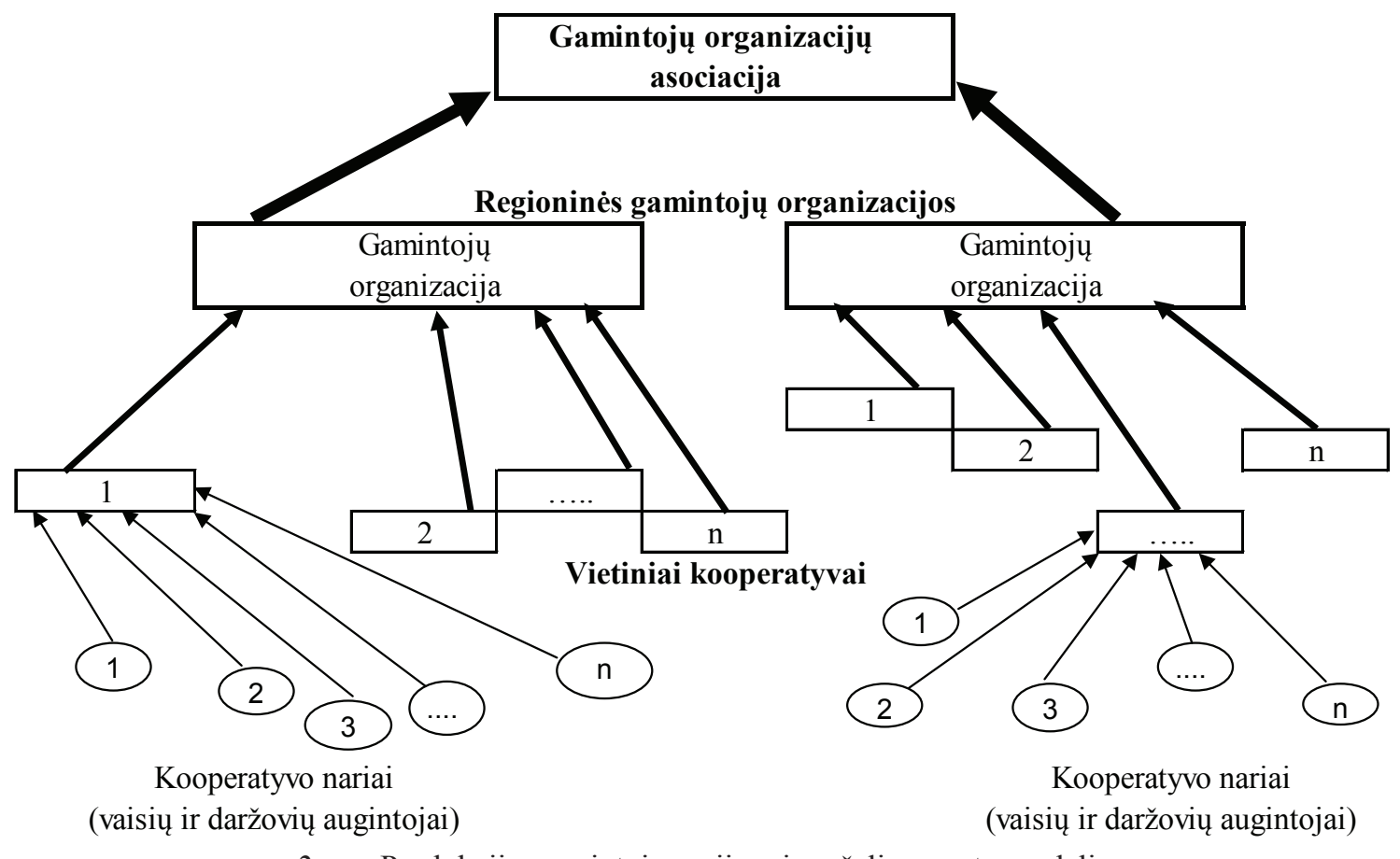

2 pav. Produkcijos augintojų susijungimo šalies mastu modelis 
Vietiniu kooperatyvų funkcijos galètų būti derliaus surinkimo ir transportavimo. Jie sutelktų nedidelès teritorijos žemės ūkio produkcijos gamintojus / augintojus (pvz., rajono). Vietinių kooperatyvų funkcija surinkti žemės ūkio produkciją iš augintojų, ją rūšiuoti ir teikti regioniniams kooperatyvams.

Vietiniai kooperatyvai, susijungę ị antrojo lygio kooperatyvus (kooperatyvų kooperatyvus), gali sukurti Regionines $G O$, kurios sutelktų didesnès teritorijos ūkininkus. Tokie kooperatyvai, steigiami vieno ar kelių rajonų mastu, apsirūpintų transporto priemonėmis, dideliais sandèliais, šaldytuvais ir pan. Šie kooperatyvai galètų sukurti trečiojo lygio kooperatyvus. Jų funkcija - šaldyti, pakuoti ir ruošti stambiąsias produkcijos partijas bei teikti jas GO asociacijoms.

GO asociacijos - kooperatyvų asociacijos, sujungiančios regionines GO (antrojo lygio kooperatyvus) ir prekiaujančios šalies bei tarptautiniu mastu. Šioms GO atsiranda didesnė galimybe įsigyti ir naudoti sudètingą, brangią įrangą, taikyti šiuolaikines technologijas, išlaikyti rinkodaros tarnybą ir pan.

Be to, įdiegus siūlomą sistemą, susidaro galimybė kooperuotis ịvairaus pajègumo ūkininkams. Yra žinoma, kad stambūs ūkininkai nenoriai vienijasi su smulkiaisiais ir mielai - su sau lygiais. Pateiktoje sistemoje numatytas atskirai stambiujų ir smulkiujų ūkininkų vietinių kooperatyvų steigimasis, pastarieji bendroms problemoms spręsti kaip lygūs partneriai nariai susijungia ị regionines ir ị GO asociacijas.

Toks GO susijungimas ị asociaciją visos šalies mastu nedidelèje šalyje ateityje yra visai realus. Susijungimas suteiktų gamintojams didelę rinkos galią, leistų geriau planuoti gamybą, vykdyti rinkodaros veiksmus ne tik šalyje, bet ir tarptautinėse rinkose. Ši modelị galètų taikyti ne tik vaisių ir daržovių, bet ir pieno gamintojai, kurie turi sukurti nedidelius vietinius kooperatyvus, kad užsitikrintų GO statusą.

Tarptautiniai kooperatyvai (GO). Steigti tarptautinius kooperatyvus ar ịsitraukti ị juos yra naudinga, nes susidaro galimybė patekti į bendrą tarptautinę rinką, taigi gerẻja rinkodara, didèja kooperatyvo apyvarta (atsiranda masto ekonomikos efektas), galima bendrų produktų gamyba, užsimezga ūkininkų ryšiai - iš dalies sprendžiamos socialinès problemos. Tačiau tokius kooperatyvus sunkiau valdyti ir kontroliuoti jų veiklą, būtina derintis prie įvairių šalių įstatymų, kalbos, atstumų ir kt.

Tačiau puikūs kooperatyvų vienijimosi ị internacionalinius kooperatyvus pavyzdžiai - danų, norvegų ir švedų pieno perdirbimo kooperatyvai. Jie, turẻdami bendrus kooperatyvus, turi didelès apyvartos pienines, kurios prekiauja visame pasaulyje. Pastebètina, kad mažosios šalys (pvz., Liuksemburgas) daug aktyviau steigia tarptautinius kooperatyvus, lyginant su didžiosiomis šalimis (pvz., Vokietija), nes pastarosios turi plačią savo vidaus rinką. Taigi, nepaisant šalių istorijos, ekonomikos, kultūros ir papročių skirtumų, vykstant pasaulejjimo (globalizacijos) reiškiniams, ekonomika vienodèja. Tai leidžia manyti, kad didès ir Lietuvos kooperatyvų internacionalizacija, vienodès organizaciniai, finansiniai, rinkodaros ir kiti kooperatyvų reglamentai.

Išvados

1. GO pripažinimui tinkamiausia įmonès forma - kooperatinė bendrovė (kooperatyvas), tačiau GO kūrimąsi stabdo kooperatyvų dydis, neužtikrinantis reikiamo per juos vykdomos prekybos apyvartos masto, kuris motyvuotų siekti GO numatytos paramos rinkodaros plètrai.

2. Formalių žemès ūkio produkcijos augintojų (gamintojų) susijungimo ị GO procesas gana sudètingas, čia iškyla daug ịvairių kliūčių: žemdirbių savitarpio pasitikẻjimo trūkumas, baimė prarasti galimybę pačiam priimti sprendimus ir būtinybė laikytis GO galiojančių taisyklių, norint būti nepriklausomais, pasirinkimas ūkininkauti savarankiškai (net ir mažesnio efektyvumo ir konkurencingumo sąskaita), menka teikiama parama, ,juodoji rinka“, sudètingos GO pripažinimo procedūros.

3. Nors Lietuvoje GO ịteisintos $2002 \mathrm{~m}$. LR Žemès ūkio ir kaimo plètros įstatyme, iki šiol sukurta tik viena vaisių ir daržovių bei trys formalios žuvininkystės GO. GO spartesnę plètrą stabdo aktualios ir neišspręstos problemos: psichologinès, ekonomikos, organizavimo, teisès ir konsultavimo srityse. Be to, GO kūrimąsi stabdo kooperatyvų dydis, neužtikrinantis reikiamo per juos vykdomos prekybos apyvartos masto, kuris motyvuotų siekti GO numatytos paramos rinkodarai plètoti. 
4. Tik didele apyvarta pasižyminčios GO gali sèkmingai pasinaudoti ES teikiama parama, todèl norint ịvairaus dydžio augintojų ūkiams susijungti ị kooperuotus darinius būtina integrali hierarchinè sistema, leidžianti struktūruoti vietinių, teritorinių ir visos šalies mastu veikiančių kooperatyvų bei GO kūrimosi procesą ir išgryninti konkretaus lygmens kooperatinių darinių veiklos turinị. Nacionalinių kooperatyvų susijungimo ị internacionalinius kooperatyvus pavyzdys - danų, norvegų ir švedų pieno perdirbimo kooperatyvai. Jie tarpusavyje susikooperavę, turi modernių, labai pajègių pieninių, gebančių savo produktus paskleisti po visą pasauli.

5. Populiarinant grupinę veiklą (GO), ịveikiant minètus barjerus, būtina kurti pozityvius bendros veiklos pavyzdžius, sudaryti galimybę naudotis kompetentingomis konsultacijomis.

6. Kooperatyvų ir GO veiklai skatinti būtina parengti ir priimti ilgalaikę strategiją, kurioje turi būti numatytos gamintojų organizacijų plètros kryptys ir pagrindinès priemonès: produkcijos realizavimas, ūkininkų ir kooperatyvų vadovų mokymai (konsultavimas), paramos gavimo supaprastinimas ir kt.

7. Žemdirbių GO kūrimosi tempams spartinti reikia aktyvesnių veiksmų, todèl smulkiems ir vidutiniams gamintojams siūlomi palankesni teisiniai sprendimai ir didesnis finansinis rèmimas. İ GO kūrimosi procesą siūloma įtraukti ị specializuotas institucijas.

\section{Literatūra}

Bingen, J. (1999). Producer Groups: Becoming Full Partners in Agricultural Markets and Agro-enterprises. Prieiga internete: http://web.worldbank.org/WBSITE/EXTERNAL/ TOPICS/EXTARD/0,,contentMDK:20445158 page PK:210058 piPK:210062 theSitePK: 336682 isCURL:Y,00.html [2015 05 14].

Boguta, W. (2014). Spótdzielczość wiejska jako jedna z głównych form wspólnego gospodarczego działania ludzi. Warszawa: Krajowa Rada Spółdzielcza.

Chazoule, C., Domagalska-Grędys, M., Pluvinage, J. (2005). Share of producer organizations and groups in the fruit market. French and polish specificity. Stowarzyszenie ekonomistów rolnictwa i agrobiznesu. Roczniki Naukowe. T. 7, Zeszyt 6, p. 17-22.

Chlebicka, A. (2011). Czynniki wpływające na sukces grup producentów rolnych. Journal of Agribusiness and Rural Development, No. 4(22), p. 59-73.

Chlebicka, A., Fałkowski, J., Wołek, T. (2008). Powstanie grup producentów rolnych a zmienność cen. Warszawa: Wyd. Fundacji Programów Pomocy dla Rolnictwa FAPA.

Dèl žemès ūkio... (2000). Žemès ūkio ir kaimo plètros strategija. LR Seimo nutarimas, Nr. VIII-1728, 2000.06.13.

Dèl LR Vyriausybès programos. (2012). Šešioliktosios Vyriausybès 2012-2016 metų programa. LR Seimo nutarimas, Nr. VIII-1728, 2000.06.13.

Desai, K. S., Schmidt, J. P., Sproul, G., Jalabert-Doury, N. (2010). The Food Sector: The competitive environment may be to blame. Mayer Brown International LLP, Brussels Office.

Development of agricultural cooperatives in the EU 2014. (2015). European agri-cooperatives (Cogeca). Prieiga internete: http://agricultura.gencat.cat/web/.content/de_departament/de02_ estadistiques_observatoris/27_butlletins/02_butlletins_nd/documents_nd/fitxers_estatics_nd/2015/0152_2015_IA_Cooperatives_Cooperatives-UE. pdf [2014 09 14].

Ejsmont, J. (2005). Grupy producentów - nowa forma spółdzielczego działania. Warszawa: Fundusz Współpracy, 16 p.

Evaluation of the national strategy for sustainable operational programmes in the fruit and vegetable sector. (2012). Prieiga internete: http://ec.europa.eu/agriculture/fruit-and-vegetables/country-files/it_en.htm [2015 02 02].

Klaassen, Ad. (2007). Implementation of CMO - regulations in the Netherlands. Management Theory and Studies for Rural Business and Infrastructure Development, No. 2 (9), p. 136-141.

Krzyżanowska, K. (2003). Przedsiębiorczość zespolowa rolników i jej uwarunkowania. Warszawa: Wyd. SGGW.

Komisijos ataskaita Europos Parlamentui ir Tarybai dèl nuostatu, susijusiu su vaisiu ir daržoviu sektoriaus gamintoju organizacijomis, veiklos fondais ir veiklos programomis, igyvendinimu po 2007 m. reformos. (2014). Prieiga internete: http://register.consilium.europa.eu/doc/srv?l=LT\&f= ST\%207312\%202014\%20INIT [2014 05 14].

Kriščiukaitienè, I., Namiotko, V., Kripaitis, R. (2015). The evaluation of the impact of support on Lithuanian farms investments. Management theory and studies for rural business and infrastructure development, Nr. 37(3), p. 399-405.

Kuliešis, G., Pareigienė, L. (2010). Nuostatų kooperuotis vertinimas. Management Theory and Studies for Rural Business and Infrastructure Development, Nr. 5 (24), p. 108-115. 
Lemanowicz, M. (2004). Czynniki sukcesu rolników działających w grupach producentów rolnych. Roczniki naukowe SERiA, T. 6, Z. 1, p. 127-132.

Oleszko-Kurzyna, B. (2007). Postawy rolników wobec grup producentów rolnych. Annales universitatis Mariae CurieSklodowska, Vol. XLI, 11, p. 161-176.

Ollila, P. (2009). Principles of Institutional Economics - with Applications to Cooperative Enterprises. University of Helsinki, Department of economics and management publications, Nr. 56.

Pareigienè, L., Ribašauskienè, E. (2008). Kooperacijos plètros vertinimas. Management Theory and Studies for Rural Business and Infrastructure Development, Nr. 12(1), p. 122-128.

Pateikti pasiūlymus ir pagristas rekomendacijas dèl atitinkančiu ES reikalavimus gamintoju organizacijų. (2001). LR ŽŪM užsakomojo mokslinio tiriamojo darbo ataskaita. Vadovas J. Ramanauskas.

Pieno gamintoju organizaciju ir ju asociaciju administravimo taisyklès. Prieiga internete: http://www3.lrs.lt/pls/inter3/ dokpaieska.showdoc_1?p_id=431373\&p_tr2=2 [2015 09 09].

Prus, P., Wawrzyniak, B. M. (2009). Grupy producentów rolnych w świetle PROW z lat 2004-2006 oraz 2007-2013. Rozwój przedsiębiorczości i zespołowej działalności gospodarczej w rolnictwie w świetle integracji z Unia Europejska. Red. nauk. S. Zawisza. Wyd. Uczelniane Uniwersytetu Technologiczno-Przyrodniczego w Bydgoszczy, Bydgoszcz, s. 151-154.

Ramanauskas, J. (2013). Šiuolaikiniai kooperatinès veiklos ypatumai. Organizaciju vadyba: sisteminiai tyrimai, Nr. 65, p. 95-108.

Report from the Commission to the European Parliament and the Council. (2014). European Commission. Brussels, 4.3.2014 $\operatorname{COM}(2014) 112$ final. Prieiga internete: http://webcache.googleusercontent.com/ search?q=cache:jyrOt0CDxOgJ:www.europarl.europa.eu/meetdocs/2014_2019/documents/com/com_ com\%282014\%290112_com_com\%282014\%290112_en.pdf+\&cd=2\&hl=lt\&ct=clnk\&gl=1t [2015 09 09].

Skulskis, V., Girgždienè, V., Mikelionyte, D. (2014). Ekologiško pieno gamybos kooperatyvo veiklos vertinimo rezultatai. Management theory and studies for rural business and infrastructure development, No. 36(2), p. 407-415.

Sposoby wspótpracy doradców z rolnikami zorganizowanymi w grupy producentów rolnych. (2008). Warszawa: Wydawnictwo SGGW.

Vaznonis, V. (2007). Kaip sukurti gamintojų organizaciją. Mano ūkis, Nr. 5, p. 8-10.

Vaznonis, V. (2014). Gamintojų organizacijų kūrimas kaip žemdirbių kooperacijos plètros Lietuvoje galimybè. Management Theory and Studies for Rural Business and Infrastructure Development. Vol. 36, No. 2, p. 435-443.

Vaznonis, V., Ramanauskienė, J., Ramanauskas, J. (2008). Vaisių ir daržovių sektoriaus strategijos koncepcija. Management Theory and Studies for Rural Business and Infrastructure Development, Nr. 4 (15), p. 200-207.

Vidickiené, D., Gedminaite, Ž. (2009). Kooperacijos plètros Lietuvoje stebėsena ir vertinimas. Management theory and studies for rural business and infrastructure development, Nr. 16 (1), p. 116-123.

Westerlund-Lind, L. (2011). Market orientation of the Swedish pork sector. PhD Thesis. Uppsala: Swedish University of Agricultural Sciences.

Wiatrak, A. P. (2015). Grupy producenckie jako forma więzi w agrobiznesie. Problemy Zarządzania, Wydziat Zarzadzania Uniwersytetu Warszawskiego, Vol. 13, Nr. 1(50), T. 1, p. 182-196.

\title{
FORMATION OF AGRICULTURALPRODUCERS ORGANIZATIONS
}

\author{
JAN ŽUKOVSKIS, JULIUS RAMANAUSKAS \\ Aleksandras Stulginskis University, Klaipėda University (Lithuania)
}

\section{Summary}

Lithuanian agricultural sector is dominated by small farms, who faces difficulties to operate under market conditions. So in order to gain competitive advantages in the management of agricultural products markets, improve product quality, to solve social and environmental issues, they need to connect to larger formations, such as cooperatives and producers' organizations (PO).

The research problem - what is broadening of PO in different countries of the EU and what measures necessary for their faster development in Lithuania? 
The aim of the research - to prepare measures for activation of farmers' producer organizations establishment.

The research methodology. The analysis of the economic literature and legal documentation of agricultural production and farmers' markets, regulatory issues cooperatives analysis. In addition, A semi-standardized interview with Lithuania and Ireland, Italy, Latvia, Poland, Holland, France, Sweden and Germany cooperatives and POs leaders and experts was applied. A long-term strategy is necessary for activation of cooperatives and PO development. Producer organizations development directions and main tools, such as the realization of production, training and consultation of farmers and heads of cooperatives, simplification of receiving support and others. Measures must be provided in such strategy.

KEYWORDS: producer organizations, cooperatives, program of actions, financial support.

JEL CLASSIFICATION: Q01, Q13, Q17.

Gauta: 2016.05.15

Priimta: 2016.05 .27

Pasirašyta spaudai: 2016.06.01 